\title{
Public health practice within Canada's military healthcare system
}

\author{
Colonel Pierre Morissette ${ }^{1 *}$
}

Suggested citation: Morissette PJ. Public health practice within Canada's military healthcare system. Can Commun Dis Rep 2020;46(9):254-5. https://doi.org/10.14745/ccdr.v46i09a01
This work is licensed under a Creative Commons Attribution 4.0 International License.

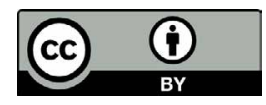

As Canadians, we have so much to be thankful for although we may not always appreciate all the benefits we enjoy just by virtue of living in a country such as Canada. The relative peace, stability and security inherent in living in an Arctic nation bordered on three sides by oceans and on the fourth by a friendly global superpower translate into the requirement for only a modest military —at best-to protect Canada and its interests from foreign aggression. Still, even a modest military needs a healthcare system that can keep its personnel fit for their duties, with the capacity to address any public health issues that might threaten them, whether at home or abroad. What follows is a brief introduction to Canada's military public healthcare system with a focus on the preventive health practice that goes on-often behind the scenes-to maintain operational readiness of Canada's military by optimizing the individual health of its personnel in uniform.

The Canadian Armed Forces (CAF) are the unified armed services of Canada, consisting of sea, land and air elements more commonly known as the Royal Canadian Navy, the Canadian Army and the Royal Canadian Air Force (1). CAF personnel currently number approximately 101,500 , including 71,500 full-time members in the Regular Force and 30,000 part-time members in the Reserve Force (1). CAF personnel are supported by an additional 25,000 civilian public service employees of the Department of National Defence (1).

Canada's Constitution Act, 1867, established the exclusive authority over matters related to Canada's "militia, military and naval service, and defence" to the federal government (2). This authority extends to healthcare services for CAF personnel who are specifically excluded from the definition of insured persons in the Canada Health Act (3). The Canadian Forces Health Services Group (CF H Svcs Gp), led by the Commander CF H Svcs Gp and Surgeon General, exists to fill this gap in the Canada Health Act by providing health services to CAF personnel across Canada as well as to those posted or deployed on military operations abroad. Generally speaking, CF H Svcs Gp provides for the comprehensive health care of CAF personnel comparable to that provided to all other Canadians by their provincial healthcare plans (4).

\begin{abstract}
Affiliation
${ }^{1}$ Directorate Force Health Protection, Canadian Forces Health Services, Ottawa, ON (at the time the article was written)

*Correspondence:

pierre.morissette@forces.gc.ca
\end{abstract}

The CF H Svcs Gp is a pan-Canadian healthcare system with significant national and international responsibilities, employing approximately 6,100 health services personnel and with an annual budget of close to $\$ 471 \mathrm{M}$, excluding CAF personnel salaries. It works alongside non-governmental organizations and other health jurisdictions at the provincial and territorial level and other federal departments with health-related interests such as Health Canada and the Public Health Agency of Canada, as well as those with health systems of their own including Indigenous Services Canada and Correctional Services Canada. Finally, it works with its military allies as part of the North American Aerospace Defence Command (NORAD), the North Atlantic Treaty Organization (NATO) and the United Nations.

In terms of operational medicine, the CF H Svcs Gp must be capable of providing the "Canadian standard" of health care-including public health-to CAF members across the full spectrum of military operations; from humanitarian assistance and disaster relief, to peacekeeping, to combat. In a military context, public health is often referred to as "force health protection", which is defined by NATO as: "all medical efforts to promote or conserve physical and mental well-being, reduce or eliminate the incidence and impact of disease, injury and death and enhance operational readiness and combat effectiveness of the forces" (5).

The public health component of CF H Svcs Gp consists of multidisciplinary preventive medicine teams at the tactical (local) and operational (regional) levels supported by subject matter experts within a strategic level headquarters located in Ottawa known as the Directorate of Force Health Protection (DFHP). 
public health (8). Please read on and enjoy learning more about how public health is currently being practiced within Canada's military healthcare system and contributing to CAF's mission successes at home and globally.

\section{References}

1. Government of Canada. National Defence Act (R.S.C. 1985, c. N-5) (modified 2019-10-01; accessed 2019-12-09). https://laws-lois.justice.gc.ca/eng/acts/N-5/FullText.html

2. Government of Canada. Constitution Act of 1867 (modified 2020-04-09; accessed 2019-12-09). https://laws-lois.justice. gc.ca/eng/Const/FullText.html

3. Government of Canada. Canada Health Act (R.S.C. 1985, c. C-6) (modified 2017-12-12; accessed 2019-12-09). https://laws-lois.justice.gc.ca/eng/acts/C-6/FullText.html

4. Government of Canada. About the CAF Spectrum of Care (modified 2019-01-15; accessed 2019-12-09). https://www.canada.ca/en/department-national-defence/ services/benefits-military/pay-pension-benefits/benefits/ medical-dental/information-management.html

5. North Atlantic Treaty Organization. NATO Standard AJMedP-4, Allied Joint Medical Force Health Protection Doctrine, Ed. A v. 1, July 2018, p 1-1. https://www.coemed. org/files/stanags/02_AJMEDP/AJMedP-4_EDA_V1_E_2561. pdf

6. Canadian Forces Joint Publication JP 4-10, Health Services Doctrine, Final Draft, March 2020, p 5-1. https://www.jcs.mil/ Portals/36/Documents/Doctrine/pubs/jp4_10.pdf

7. Adami JG. War Story of the Canadian Army Medical Corps. Vol 1. The First Contingent (to the Autumn of 1915). Published for the Canadian War Records Office (accessed 2019-12-19). https://digital.library.upenn.edu/women/adami/ camc/camc.html

8. Government of Canada. National Defence. Strong Secure Engaged: Canada's Defence Policy. DND: 2017 (accessed 2020-01-21). https://www.canada.ca/en/ department-national-defence/corporate/ reports-publications/canada-defence-policy.html
It follows that, to ensure Canada remains strong at home, secure in North America and engaged in the world, it is important for its relatively small military to maintain an effective capability in 